\title{
Histological study of the dynamics in epidermis regeneration of the carp tail fin (Cyprinus carpio, Linnaeus, 1758)
}

\author{
Böckelmann, $P K .^{\mathrm{a}}$, Ochandio, BS. ${ }^{\mathrm{b}}$ and Bechara, IJ. ${ }^{\mathrm{a} *}$ \\ ${ }^{a}$ Laboratório de Histofisiologia e Histopatologia Experimental em Ectotérmicos, \\ Departamento de Histologia e Embriologia, Instituto de Biologia, \\ Universidade Estadual de Campinas - UNICAMP, \\ CP 6109, CEP 13083-970, Campinas, SP, Brazil

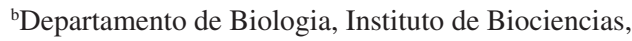 \\ Universidade Estadual Paulista "Júlio de Mesquita Filho" - UNESP, \\ Av. 24 A, 1515, CEP 13506-900, Rio Claro, SP, Brazil \\ *e-mail: ibechara@unicamp.br
}

Received December 3, 2008 - Accepted March 26, 2009 - Distributed February 28, 2010

(With 9 figures)

\begin{abstract}
Teleostean fins when partially amputated suffer a regenerative process called epimorphic regeneration, characterized by the following stages: healing, based on the formation of a multistratified epidermal layer, the formation of a mass of pluripotent cells known as blastema, the differentiation of these cells, the synthesis and disposition of the extracellular matrix, morphological growth and restoration. The epidermis has a fundamental role in the regenerative process of fish fins, as the healing time of this structure leads it to a faster regenerative process and it also works as a defense against the external environment. In this sense, due to the fast regeneration shown by the epidermis, the aim of this paper is to study the histology of the regenerative dynamics of the carp fin tail (Cyprinus carpio), under the light and transmission electron microscope. Epidermic regeneration begins right in the first hours after the fin amputation and it continues throughout the regenerative process. After 24 hours, an apical epidermal cap is established. Cytoplasmatic prolongations and intercellular junctions are observed and the cells of the basal layer of the epidermis change from the cubic form to the cylindrical, due to the development of the cytoplasmatic organelles responsible for the synthesis of the basal membrane, lost after amputation. These results show the importance of histological studies in regenerative processes. We believe that the association of molecular biology with histological studies can throw further light onto these regenerative dynamics.
\end{abstract}

Keywords: regeneration, fin, fish, epidermis, transmission electron microscopy.

\section{Estudo histológico da dinâmica da regeneração da epiderme da nadadeira caudal da carpa (Cyprinus carpio Linnaeus, 1758)}

\begin{abstract}
Resumo
As nadadeiras dos teleósteos, quando parcialmente amputadas, sofrem um processo de regeneração chamado de regeneração epimórfica, caracterizado pelas seguintes fases: cicatrização, a partir da formação de uma capa epidermal multiestratificada, formação de uma massa de células mesenquimais multipotentes chamada blastema, diferenciação dessas células, síntese e deposição de matriz extracelular, crescimento e restauração morfológica. A epiderme tem papel fundamental no processo regenerativo das nadadeiras dos peixes, uma vez que a velocidade de cicatrização dessa estrutura leva a um processo regenerativo mais rápido e, também, age como uma defesa contra o ambiente externo. Assim, devido à rápida regeneração que a epiderme apresenta, tivemos como objetivo, neste trabalho, estudar a histologia da dinâmica regenerativa da epiderme das nadadeiras caudais da carpa (Cyprinus carpio) ao microscópio de luz e eletrônico de transmissão. A regeneração da epiderme tem início já nas primeiras horas após a amputação das nadadeiras e continua durante todo o processo regenerativo. Após 24 horas, uma capa epidermal apical é estabelecida. Prolongamentos citoplasmáticos e junções intercelulares são observados e as células da camada basal da epiderme passam da forma cúbica para a cilíndrica, devido ao desenvolvimento das organelas citoplasmáticas responsáveis pela síntese da membrana basal perdida após a amputação da nadadeira. Estes resultados mostram a importância de estudos histológicos em processos regenerativos. Acreditamos que a associação da biologia molecular a estes estudos histológicos poderá elucidar ainda melhor esta dinâmica regenerativa.
\end{abstract}

Palavras-chave: regeneração, nadadeira, peixe, epiderme, microscopia eletrônica de transmissão. 


\section{Introduction}

The general structure of teleostean fins consists of skeletal structures known as lepidotrichia (fin rays) and actinotrichia, both surrounded by connective tissue and skin (Montes et al., 1982; Becerra et al., 1983; Santamaría and Becerra, 1991; Géraudie and Singer, 1992).

The skin that covers the teleostean fins is constituted by the epidermis and the dermis. The epidermis, the most superficial and external layer of the skin, is composed of a stratified squamous epithelium. The dermis, the internal layer located immediately under the epidermis, is constituted by conjunctive tissue. (Becerra et al., 1983).

The epidermis has a fundamental role in the regenerative process of fish fins (Becerra et al., 1983; Akimenko et al., 1995), since the healing time of this structure leads to a faster process, avoiding specially, infective biotic processes by microorganisms found in water environments, such as fungus, bacteria and protozoan that can transmit diseases. These microorganisms can take advantage of the physical damage and install themselves in these places generating infections that can interfere in the healing and consequently the restoration of the wounded parts. Epidermis regeneration has, in this sense, a vital function as a defense against the external environment (Quilhac and Sire, 1999).

Normally, the healing process follows a sequence of cellular and biochemical events that result in the restoration of the epidermis (Radice, 1980a; 1980b; Pollack, 1984; Vanable, 1989). Similar to the regeneration that occurs with amphibians, the regeneration of teleostean fins has fundamental distinctions during this process, as it presents in the wound healing, the first step for all the following processes. Differentiation, which leads to blastema formation, is also very important, as well as cellular differentiation, morphologic growth and restoration (Nabrit, 1929; Goss and Stagg, 1957; Haas, 1962; Santamaría and Becerra, 1991; Géraudie and Singer, 1992; Becerra et al., 1996; Bechara et al., 2000).

In the regenerative process and in the tail fin healing, the epidermis cells reconstitute themselves and form an apical epidermal cap (Santos-Ruiz et al., 2002). The presence of this epidermal layer is extremely important in order to stimulate the regeneration of other lost structures of the fin (Goss, 1991).

Therefore, due to the importance of this regenerative epidermic process, particularly for fishes bred in fisheries, we studied in the present paper the dynamics in the epidermis regeneration of the carp tail fin (Cyprinus carpio) kept in lab conditions at a temperature of $26^{\circ} \mathrm{C}$, under light and transmission electron microscope analysis. This work can add to the teleostean regenerative model, that has already been shown to be an excellent model to work with when studying tissue regeneration (Becerra et al., 1996; Bechara et al., 2000; Bechara et al., 2003; Böckelmann and Bechara, 2004; Böckelmann and Bechara, 2007) and that has shown to be equally important as a tool to be associated to molecular biology and for the studies of genetic expression, especially due to the dimorphic processes found in this dynamic.

\section{Material and Methods}

In the experiment, fish were used from the Cyprinus carpio species, purchased from a commercial supplier and measuring from five to seven centimetres long. The animals were kept at the Histology and Embryology Fish Bioassay Laboratory at Unicamp`s Biology Institute, in Campinas, SP, in quarantine, in plastic aquaria, with clean dechlorinated water, at $26^{\circ} \mathrm{C}$, with constant aeration and fed daily with appropriate fish food.

At the beginning of the experiment, 16 fish were transferred to a glass aquarium with $10 \mathrm{~L}$ of clean and dechlorinated water with constant aeration. The water was kept at $26{ }^{\circ} \mathrm{C}$ during the whole experiment. The photoperiod was of 12 hours (light/dark) and all the fish were fed daily. Twenty-four hours later, all the fish were anesthetised, one by one, with benzocaine (1:10000) (SYNTH, Brazil) and had their tail fin transversally amputated $3 \mathrm{~mm}$ from the tail muscular peduncle with a sharp knife (according to Becerra et al., 1996). After amputation, the fish were returned back to their aquarium so that the regenerative study could begin.

After 1, 2, 3 and 4 days of amputation, the animals were sacrificed through anaesthesia deepening and the regenerative fins were excised and processed to permit observation under a light and transmission electron microscope. Four specimens were used for each interval.

Half of each collected fin was immediately fixed in Bouin solution for 6 hours, paraffin-embedded and sectioned at $6 \mu \mathrm{m}$ thick. The sections were stained with picrosirius-hematoxylin (Junqueira et al., 1979) and observed under a conventional light microscope. As for the electron microscope analysis, the other half of the fin collected was cut in small fragments and which were fixed in Karnovsky, for 4 hours at $4{ }^{\circ} \mathrm{C}$, rinsed in a solution of Phosphate buffer $0.1 \mathrm{M}$ (pH 7.4) with sacharide at $7.5 \%$ and after, post-fixed in a solution of Osmium $1 \%$ with Phosphate buffer $0.2 \mathrm{M}$ for 1 hour at $4{ }^{\circ} \mathrm{C}$. The samples were then washed with glucose saline, dehydrated in growing concentrations of acetone, pre-embedded in a mixture of acetone and epon (1:1) for 3 hours and drenched in pure epon for 24 hours. The tissue fragments were polimerised in oven at $60{ }^{\circ} \mathrm{C}$ for 48 hours. Thin cuts $(1 \mu \mathrm{m})$ were obtained in ultramicrotome LEICA (Germany) and hot coloured with toluidine blue. After that, extra thin cuts (60-70 nm) were obtained and contrasted with uranyl acetate and lead citrate and examined and micrographed with a transmission electron microscope (LEO 906, Germany).

\section{Results}

Epidermic regeneration occurred in all the specimens analysed, showing regeneration right on the first day after fin excision. Twenty-four hours after amputation, the cells had already migrated to cover the wounded sur- 
face and formed an apical epidermal cap (thick layer of epithelium cells) (Figure 1). Meanwhile, the epidermis that covered the rest of the fin, and that had not suffered any amputation, continued in its normal size, which was smaller than that of the apical epidermal cap (Figure 1).

Observations under the transmission electron microscope showed that the cells forming the apical epidermal cap, when migrating to the amputated extremity of the fin, emitted cytoplasmatic prolongations (Figures 2 and 3), that left spaces between one cell and another (Figures 2 and 3 ). It is also possible to observe the presence of intercellular junctions between the epidermal cells (Figure 2).

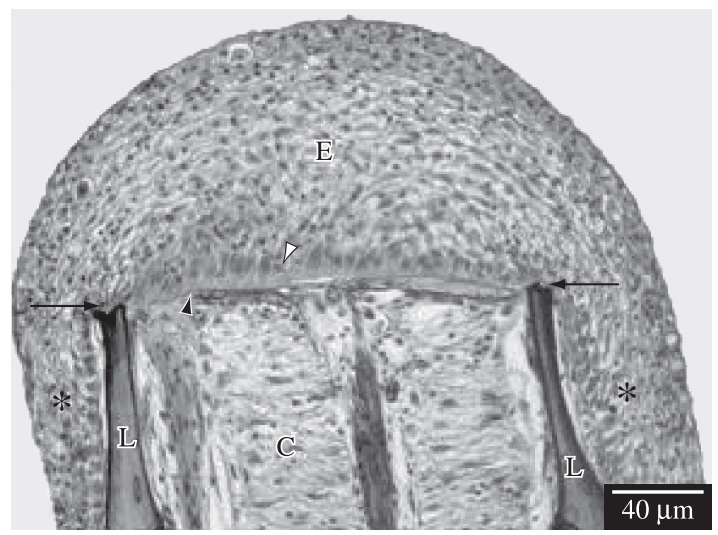

Figure 1. Longitudinal section of the distal region of the caudal fin of a fish on its first day of regeneration, observed under a light microscope. Note the apical epidermal cap (E), the cells of the epidermis basal layer with well-developed cylindrical cells (white arrow head), the epidermis basal membrane (black arrow head), the conjunctive tissue (C), the epidermis that did not suffer amputation (black asterisks), the lepidotrichia (L) and the fin amputation plane (arrows).

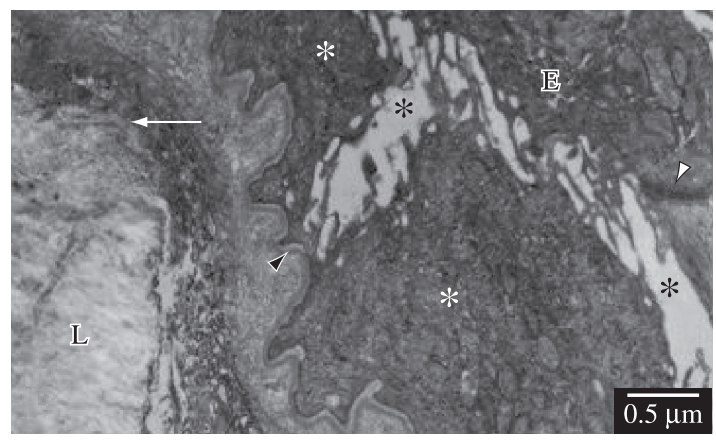

Figure 2. Longitudinal section of the distal region of the caudal fin of a fish on its first day of regeneration, observed under a transmission electron microscope (TEM). Note some apical epidermal cap cells (E), intercellular spaces (black asterisks), intercellular junction (white arrow head), epidermis basal layer cells (white asterisks), basal lamina from the epidermis (black arrow head), the lepidotrichia (L) and the fin amputation plane (white arrow).
On the other hand, the cells from the epidermal basal layer were well-developed and they formed a single layer of cylindrical cells (Figures 1 and 2). In this period of regeneration, the cells from the basal layer had already initiated the synthesis of the basal lamina located right beneath the new regenerated epithelium (Figures 2 and 3), which had been lost at the time of the fin amputation.

On the second day after amputation, the apical epidermal cap continued well-developed (Figure 4) as well as the cells from the epithelium basal layer (Figure 4 and 5). It is possible to clearly observe the intercellular spaces between the apical epidermal cap and also a slight growth of the conjunctive tissue, which was the responsible for promoting the distance between the epidermal basal layer and the lepidotrichia that was sectioned in the amputation plane (Figures 4 and 5).

In 3 days of regeneration, changes were not observed in the epidermal cap when compared to the previous days of regeneration (Figure 6). The cells of the epidermal basal layer continued to be well-developed, forming a single layer of cylindrical cells, as observed in the first day of regeneration and continued producing a basal membrane right underneath the epithelium in regeneration (Figure 6). In this period of regeneration, the blastema could be observed and it was constituted by an agglomerate of cells in the distal extremity of the fins in

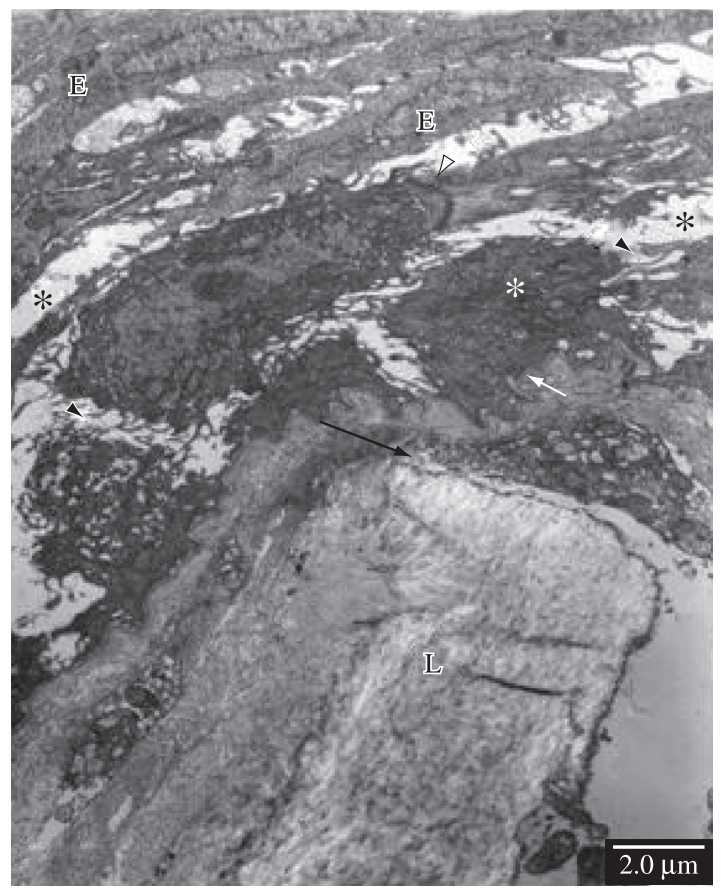

Figure 3. Longitudinal section of the distal region of the caudal fin of a fish on its first day of regeneration, observed under TEM. Note some cells from the apical epidermal cap (E), intercellular spaces (asterisks), intercellular junction (white arrow head), cytoplasmatic prolongations (black arrow heads), epidermis basal layer cells (white asterisk), basal lamina from the epidermis (white arrow), the lepidotrichia (L) and the fin amputation plane (black arrow). 


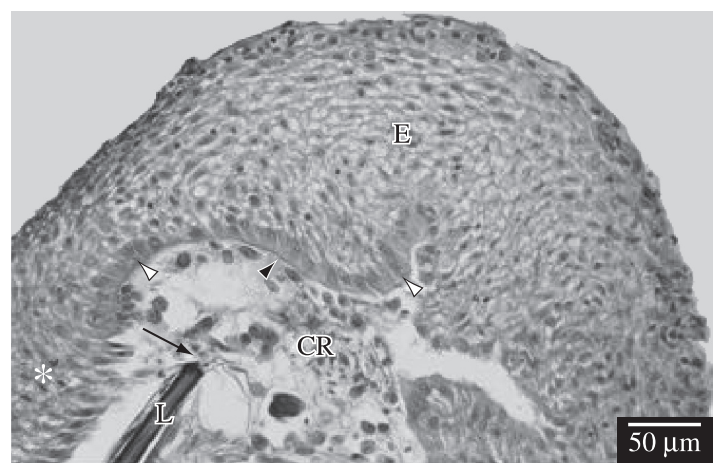

Figure 4. Longitudinal section of the distal region of the caudal fin of a fish with 2 days of regeneration, observed under a light microscope. Note the apical epidermal cap (E), the cells of the epidermis basal layer (white arrow head), the epidermis basal membrane (black arrow head), the conjunctive tissue in regeneration (CR), the epidermis that did not suffer amputation (white asterisk), the lepidotrichia (L) and the fin amputation plane (arrow).

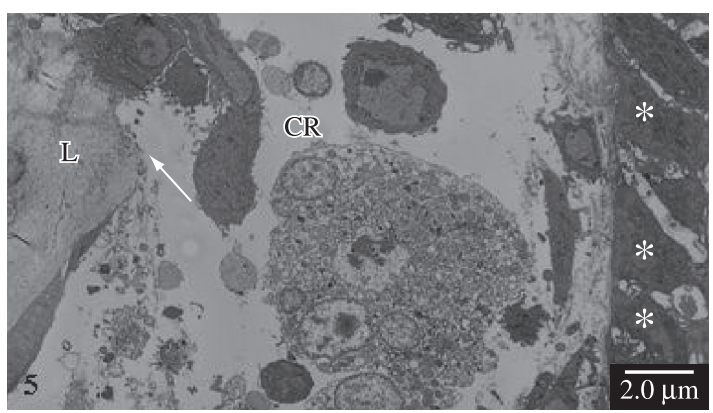

Figure 5. Longitudinal section of the distal region of the caudal fin of a fish with 2 days of regeneration, observed under TEM. Note the cells of the epidermis basal layer (white asterisks), the conjunctive tissue in regeneration (CR), the lepidotrichia (L) and the fin amputation plane (arrow).

regeneration in the conjunctive tissue beneath the epidermis. The regenerated region of the fin can be seen, as a whole, to be more developed (Figure 6).

On the fourth day of regeneration, the healed part of the fin had grown (Figure 7) and it was possible to observe a diminution of the epidermis width, as well as the reduction of the intercellular spaces (Figures 7 and 8), when compared to the previous days after amputation. Also, we noticed that the epithelium that covered the regenerative region presented a similar width to the one of the epithelium that covered the region that did not suffer amputation and therefore did not regenerate (Figure 7). In this period, the blastema was shown to be as developed as on the third day of regeneration, always located in the interior of the conjunctive tissue of the distal extremity of the fin in regeneration (Figure 7). In this period of regeneration, the cells of the epidermal basal layer continued cylindrical (Figures 8 and 9) indicating that they were still in the synthesis activity of the epithelium basal membrane (Figure 8).

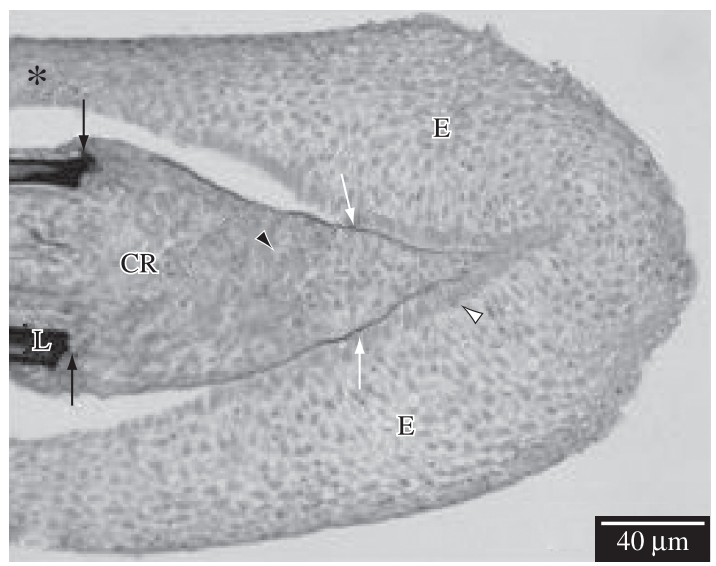

Figure 6. Longitudinal section of the distal region of the caudal fin of a fish with 3 days of regeneration, observed under a light microscope. Note the apical epidermal cap (E), the cells of the epidermis basal layer (white arrow head), the epidermis basal membrane (white arrows), the conjunctive tissue in regeneration (CR), the blastema (black arrow head), the epidermis that did not suffer amputation (asterisk), the lepidotrichia (L) and the fin amputation plane (black arrows).

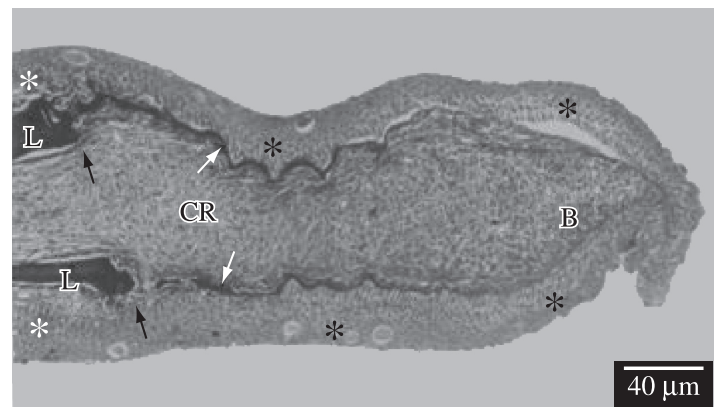

Figure 7. Longitudinal section of the distal region of the caudal fin of a fish within 4 days of regeneration, observed under a light microscope. Compare the epidermis that did not suffer amputation (white asterisks) with the epidermis that suffered amputation, and is therefore regenerating (black asterisks) Note the conjunctive tissue in regeneration (CR), the blastema (B), the lepidotrichia that did not suffer amputation (L), the lepidotrichia in regeneration (white arrows) and the fin amputation plane (black arrows).

\section{Discussion}

The fins of the teleost fish have a relatively simple and symmetric structure, with a limited number of cell types. When they suffer injury or even when amputated, they present an extremely fast capacity to regenerate all their structures. This process is known as epimorphic regeneration and it involves the fast regeneration of the epidermis in order to allow the healing of the wounded region. This is a fundamental phase and it highlights the importance of the epidermis and the velocity at which it completely regenerates. 


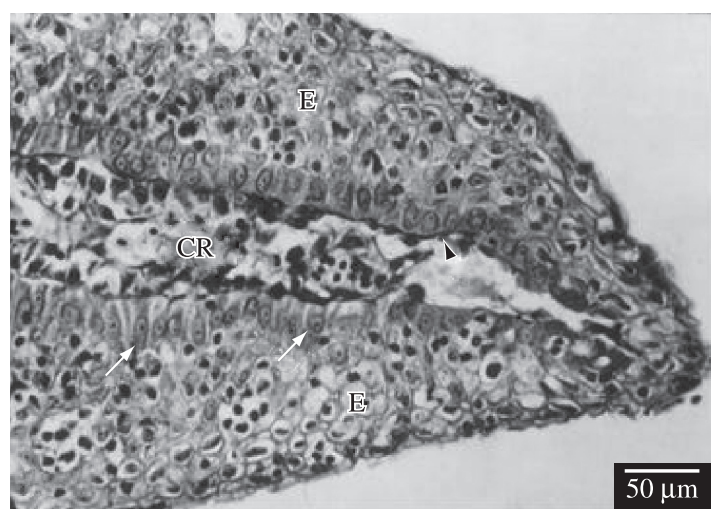

Figure 8. Longitudinal section of the distal region of the caudal fin of a fish within 4 days of regeneration, observed under a light microscope. Note the epidermis in regeneration (E), the conjunctive tissue in regeneration (CR), the epithelium basal layer with well-developed cylindrical cells (white arrows) and the basal membrane (black arrow head).

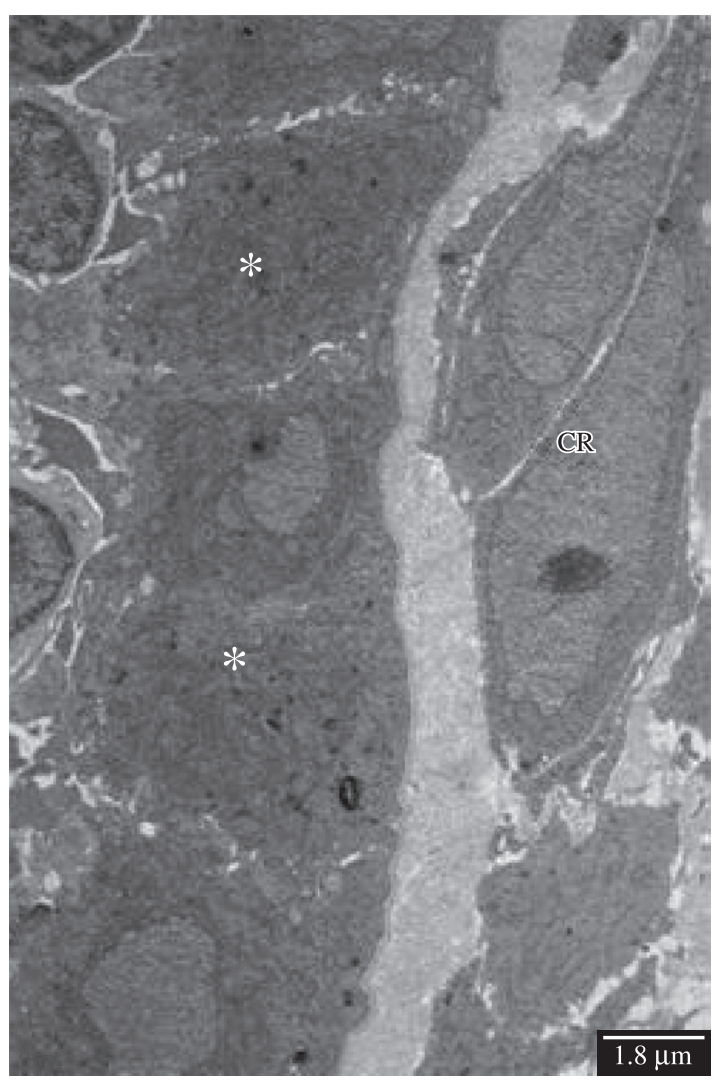

Figure 9. Longitudinal section of the distal region of the caudal fin of a fish within 4 days of regeneration, observed under TEM. Note the cells from the epidermis basal layer (white asterisks) and the conjunctive tissue in regeneration (CR).

During the regenerative process, right in the first hours after amputation, the cells of the lateral epidermis, that did not suffer any damage, migrate to the amputated region of the fin in order to cover the wound in a fast way. In sequence, the cells of the epidermis basal layer go through a dimorphism, changing from their original cubic form to a cylindrical one, when observing the production of the basal membrane. This dimorphic phase is an indication of a synthesis process, generated by the expression of the genes involved in the production of components that constitute the biochemical base of the basal membrane.

Molecular studies on the regeneration of zebrafish fins have shown the expression of $\beta$-catenin in the healing epidermic cells in the first hours after amputation and kept through the whole process (Poss et al, 2000). It is assumed that the expression of the $\beta$-catenin works in the maintenance of the interaction cell-cell that facilitate the migration of the epidermis cells and in the maintenance of the epidermis (Poss et al., 2003). Another gene detected in the epidermal cap, especially in the epidermis basal layer, in the last stages of regeneration, is the gene Wnt5. The expression of this gene seems to be strongly related to the blastema formation, leading us to suspect that the mature epidermal cap is the source of the growing factors that stimulate the formation and maintenance of the function of the blastema in regeneration, since when absent in the epidermal cap, no generation occurs (Goss, 1991; Poss et al., 2000).

Other molecular studies suggest that the gene lef1, a member of the signalling pathway Wnt, is essential to the epithelial-mesenchymal interactions in vertebrate growth, as for example, teeth growth, hair follicles and mammal gland growth. In fish, Poss et al. (2000) observed that lef1 is expressed in the recently-formed epidermal basal layer of the fin in regeneration and it is kept in the epidermal basal layer during blastema formation.

In this sense, the importance of the epidermis is verified in a first phase where the healing of the wound is involved, due to cell migration, wound healing and the protection of the fish against biotic and abiotic factors of the external environment, and in the second dimorphic phase, where the regeneration of the basal membrane allows the organisation of the blastema in order to lead the regenerative process as a whole. The dynamics, in the sense of regeneration velocity, is also mentioned as an important factor in zebrafish regeneration, as shown by Santamaría et al. (1996), Poleo et al. (2001), Nechipouk and Keating (2002), Santos-Ruiz et al. (2002) and Santos-Ruiz et al. (2005), where on the first 3 hours after amputation, a thin layer of epidermal cells migrate to cover the wound. This migration is based on studies where epidermal cells were marked with bromodeoxiuridin (BrdU) and showed that the wound healing did not occur by cell proliferation but by cell migration (Santos-Ruiz et al., 2002). After 12 to 18 hours of amputation, the epidermis accumulates extra cell layers and this process of maturation also seems to happen due to cell migration and not cell proliferation (Santos-Ruiz et al., 2002).

Our observations, under the light microscope and, even better observed, under the transmission electron microscope, allowed us to verify that the cells that form the apical epidermal layer when migrating to the 
amputated extremity of the fin, emitted cytoplasmatic prolongations. Probably, the source of width growth of the regenerative epidermis, that gives origin to the epidermal layer, is the appearance of these prolongations, which leave spaces between the cells, since they did not suffer mitotic division, as observed by Santamaría et al. (1996). The presence of intercellular junctions between the cells, showing a bigger adherence among these cells, also indicates the efficiency of the epidermal layer defense against possible water microorganism attacks, such as fungus, bacteria and protozoan, avoiding, therefore, infective biotic processes.

In our studies, using carp as a biological model, the beginning of a proliferate mass of multipotent progenitor cells denominated blastema was observed on the third day of regeneration, which was shown to be more developed on the fourth day of regeneration and from then on, the reconstitution of the complex tissue surrounding multiple cell types was observed, in other words, the reconstruction of the lepidotrichia, actinotrichia, conjunctive tissue, vases and nerves, as observed before in our previous studies (Becerra et al., 1996; Bechara et al., 2000; Bechara et al., 2003; Böckelmann and Bechara, 2004; Böckelmann and Bechara, 2007). This is also observed in zebrafish (Akimenko et al., 2003).

In the present study, the research was conducted until the fourth day of regeneration. It was verified on the first and second day after amputation, the healing of the wounded location and the formation of an apical epidermal layer and on the third to the fourth day, the reduction in the width of the epidermis. Nonetheless, little is known about the signs that govern the formation of the wounded epidermis and its different layers.

Thus, we reinforce the importance of the epidermis as the main factor in the regenerative process. Molecular studies in conjunction with histological observations should be conducted in order to improve comprehension of the process as it can also contribute to the elucidation of failures during regeneration, which leads to different consequences in the reconstruction of the carp tail fins when evaluated in the face of drugs, external abiotic agents, that in some cases will not lead to a satisfactory regeneration (Bechara et al. 2000, 2003).

In this sense, we suggest that the feasibility of histological studies with the light and transmission electron microscope, allow us to observe the process from amputation until the healing of the wound, with all the cellular processes involved, and the importance of these processes in cellular dimorphism, in blastem formation and in the regeneration of the teleostean tail fin. We also suggest the association of molecular tools in order to verify morphogenic alterations in all the healing phases of the epidermis reconstitution, contributing to posterior studies in Brazilian species, like the pacu or the curimbatá, or even hybrid species like patinga.
Acknowledgements - The authors are grateful to CAPES/DS for their financial support of this research. The authors also wish to thank the "Recanto dos Peixes" Fishing Club for providing the fish, and Sr. Baltazar Pereira de Paula for technical assistance with the fish.

\section{References}

AKIMENKO, M., MARÍ-BEFFA, M., BECERRA, J. and GÉRAUDIE, J., 2003. Old questions, new tools, and some answers to the mystery of fin regeneration. Developmental Dynamics, vol. 226, no. 2, p. 190-201.

AKIMENKO, MA., JOHNSON, SL., WESTERFIELD, M. and EKKER, M., 1995. Differential induction of four msx homeobox genes during fin development and regeneration in zebrafish. Development, vol. 121, no. 2, p. 347-357.

BECERRA, IJ., MONTES, GS., BEXIGA, SRR. and JUNQUEIRA, LCU., 1983. Structure of the tail fin in teleosts. Cell and Tissue Research, vol. 230, no. 1, p. 127-137.

BECERRA, J., JUNQUEIRA, LCU., BECHARA, IJ. and MONTES, GS., 1996. Regeneration of fin rays in teleosts: a histochemical, radioautographic, and ultrastructural study. Archives of Histology and Cytology, vol. 59, no. 1, p. 15-35.

BECHARA, IJ., BÖCKELMANN, PK., MONTES, GS. and CRUZ-HÖFLING, MA., 2003. Inhibition of caudal fin actinotrichia regeneration by acetylsalicylic acid (aspirin) in teleosts. Brazilian Journal of Morphological Sciences, vol. 20, no. 2, p. 67-74.

BECHARA, IJ., JOAZEIRO, PP., MARÍ-BEFFA, M., BECERRA, J. and MONTES, GS., 2000. Collagen-affecting drugs impair regeneration of teleost tail fins. Journal of Submicroscopic Cytology and Pathology, vol. 32, no. 2, p. $273-280$

BÖCKELMANN, PK. and BECHARA, IJ., 2004. Effect of naproxen on tail fin regeneration in teleost. Journal of Submicroscopic Cytology and Pathology, vol. 36, no. 1, p. $55-64$.

2007. Histochemical and ultrastructural study of the action of naproxen on tail fin regeneration of teleost. Brazilian Journal of Morphological Sciences, vol. 24, no. 1, p. 17-24.

BROCKES, J. and KUMAR, A., 2002. Plasticity and reprogramming of differentiated cells in amphibian regeneration. Nature Reviews Molecular Cell Biology, vol. 3, no. 8 , p. $566-574$.

GÉRAUDIE, J. and SINGER, M., 1992. The fish fin regeneration. In SAUER, HW. (Ed.). Keys to regeneration. Monographs in Developmental Biology, vol. 23, p. 62-72.

GOSS, R. and STAGG, M., 1957. The regeneration of fins and fin rays in Fundulus heteroclitus. Journal of Experimental Zoology, vol. 136, no. 3, p. 487-507.

GOSS, R., 1991. The natural history (and mystery) of regeneration. In Dinsmore CE editor. A history of regeneration research. Millestones in the evolution of a science. Cambridge: Cambridge University Press, p. 7-23.

HAAS, HJ., 1962. Studies on mechanisms of joint and bone formation in the skeleton rays of fish fins. Developmental Biology, vol. 5, no. 1, p. 1-34. 
JUNQUEIRA LCU., BIGNOLAS, G. and BRENTANI, RR., 1979. Picrosirius staining plus polarization microscopy, a specific method for collagen detection in tissue sections. Histochemical Journal, vol. 11, no. 4, p. 447-455.

MONTES, GS., BECERRA, J., TOLEDO, O., GORDILHO, M. and JUNQUEIRA, LCU., 1982. Fine structure and histochemistry of the tail fin ray in teleosts. Histochemistry, vol. 75 , no. 3, p. 363-376.

NABRIT, SM., 1929. The role of the rays in the regeneration in the tail fins of fishes in Fundulus and Goldfish. The Biological Bulletin, vol. 56, no. 4, p. 235-266.

NECHIPORUK, A. and KEATING, MT., 2002. A proliferation gradient between proximal and $m s x b$-expressing distal blastema directs zebrafish fin regeneration. Development, vol. 129, no. 11 , p. 2607-2617.

POLEO, G., BROWN, CW., LAFOREST, L. and AKIMENKO, MA., 2001. Cell proliferation and movement during early fin regeneration in zebrafish. Developmental Dynamics, vol. 221, no. 4 , p. 380-390.

POLLACK, SV., 1984. The wound healing process. Clinical Dermatology, vol. 2, no. 3, p. 8-16.

POSS, K., SHEN, J. and KEATING, M., 2000. Induction of lef1 during zebrafish fin regeneration. Developmental Dynamics, vol. 219 , no. 2 , p. $282-286$.

POSS, KD., KEATING, MT. and NECHIPORUK, A., 2003. Tales of Regeneration in Zebrafish. Developmental Dynamics, vol. 226 , no. 2 , p. 202-210.

QUILHAC, A. and SIRE, J., 1999. Spreading, proliferation, and differention of the epidermis after wounding a cichlid fish,
Hemichromis bimaculatus. The Anatomical Record, vol. 254, no. 1, p.435-451

RADICE, GP., 1980a. The spreading of epidermal cells during wound closure in Xenopus larvae. Developmental Biology, vol. 76 , no. 1, p. 26-46.

1980b. Locomotion and cell-substrate contacts of Xenopus epidermal cells in vitro and in situ. Journal of Cell Science, vol. 44, no. 1, p. 201-223.

SANTAMARÍA, J. and BECERRA, J., 1991. Tail fin regeneration in teleosts: cell-extracellular matrix interaction in blastemal differentiation. Journal of Anatomy, vol. 176, p. 9-21.

SANTAMARIA, JA., MARÍ-BEFFA, M., SANTOS-RUIZ, L. and BECERRA, J., 1996. Incorporation of bromodeoxyuridine in regenerating fin tissue of the goldfish Carassius auratus. Journal of Experimental Zoology, vol. 275, no. 4, p. 300-307.

SANTOS-RUIZ, L., SANTAMARÍA, JA. and BECERRA, J., 2005. Cytoskeletal dynamics of the teleostean fin ray during fin epimorphic regeneration. Differentiation, vol. 73, no. 4, p. $175-187$

SANTOS-RUIZ, L., SANTAMARÍA, JA., RUIZ-SÁNCHEZ, J. and BECERRA, J., 2002. Cell proliferation during blastema formation in the regenerating teleost fin. Developmental Dynamics, vol. 223, no. 2, p. 262-272.

VANABLE, JW., 1989. Integumentary potentials and wound healing. In: Eletric fields in vertebrates repair. New York: Alan R. Liss, Inc. vol. 5, p. 171-224. 